\title{
Postmodernist Features in Graham Swift's Last Orders
}

\author{
Razieh Abdi \\ English Department, Faculty of Fore ign Languages, University of Isfahan, Isfahan, Iran \\ Pyeaam Abbasi \\ English Department, Faculty of Foreign Languages, University of Isfahan, Isfahan, Iran
}

\begin{abstract}
The present essay explores the postmodernist features in Graham Swift's Last Orders (1996). The novel is in deep intertextual debt to William Faulkner's As I Lay Dying (1930) because of superficial similarities in plot, multiple narrators, and various chapters, as well as thematic elements which led to winning 1996 James Tait Black Memorial Prize for fiction and the Booker Prize. Although both modern and postmodern tendencies can be found in S wift's novel, this study endeavors to analyze overt postmodernist features in this work as a postmodernist model in literature. The selected literary work is analyzed in accordance with the peculiar notions and theories that are more visible in Swift's dramatic achievements including Jean-Francois Lyotard's theory of the end of grand narratives and Jacque Derrida's deconstruction. As an instance of a postmodernist work of art, $S$ wift's Last Orders seems to indude ambiguity, complexity, differance, pluralism, uncertainty, and decentralization that are varieties of language games. These features pertain to character, resistance to interpretation, delogocentrism, and minimalism.
\end{abstract}

Index Terms - Graham Swift, Last Orders, postmodernism, intertextuality, differance

\section{INTRODUCTION}

Last Orders written by Graham Colin Swift FRSL (1996), and noteworthy for similarities in plot to William Faulkner's As I Lay Dying (1930), is the winner of the 1996 James Tait Black Memorial Prize for fiction and the Booker Prize in 1996. Many critics have argued in favour of the dominance of modern ist features in the novel however, the application of Lyotard's theory of the end of grand narratives and Jacques Derrida's deconstruction, prove the novel to be postmodernist.

Last Orders is constructed on a one-day journey of four male characters with the aim of scattering their deceased friend's ashes in Margate Pier. However, they philosophize, ponder, and agonize over grand is sues like meaning of life and death during the course of the novel. Parker (2003) states that "Jack's death symbolizes the demise of the model of masculinity he represents and prompts his friends to reflect on their lives and reappraise their identities during the journey to Margate" (p. 91). The story is retold by multiple narrators: the whole novel is narrated in first person by seven different people that are in seventy five sections without numbers but entitled according to the name of narrators or places. The majority of the novel is narrated by four men-Vic, Vince, Lenny, and Ray — who are accompanying Jacks' ashes. A few sections of the novel are narrated by three other characters who are the dead Jack Dodds himself, Amy (Jacks' wife), and Mandy (Vince's wife) though their narration is not as dominant as the other four characters'. June's voice, A my's and Jacks' retarded daughter, is conspicuously absent in the novel. On the whole, these seventy five narrative sections, in first person, merge the descriptions of the past and disclose the secrets and mysterious events through interior monologues and result in investigation and complication of the meaning of these incidents. Swift puts it with a postmodernist sensibility that the novel is "about death in order to be about life" (as cited in Parker, 2003, p. 89). Parker presumes that "if Last Orders is about life" it is particularly about "the difficulties of how to live as a man and express maleness when traditional models of manly being have lost their validity, that is in a world in which last orders have metaphorically been called for masculinity" (Parker, 2003, p. 89). In addition, Wheeler (1999) rightly puts forward the idea that "Swift's fiction explores the loss of traditional forms of knowledge in a secular postmodern world and is concerned with the new ways of being in the face of uncertainty" (pp. 64-65). Part of the uncertainty of the world of Last Orders comes from interte xtuality.

\section{INTERTEXTUALITY}

Intertextuality is a general and neutral term that is used in place of the traditional 'reference' or 'allusion.' It is pertinent to the idea that the existing relationship between earlier and contemporary texts constitutes their meaning (Gale, 2000). The relationships of texts to other texts have been the preoccupation of literary theorists from classical antiquity until now; "Aristotle speculated on the potential shape of tragedies based on the Iliad and the Odyssey as against other relations of the fall of Troy and its consequence" (Bauman, 2004, p. 1). The term 'intertextuality' was used for the first time by Julia Kristeva in the 1960s. Intertextuality has taken on a significant role within cultural and literary 
studies. This term is drawn upon in Structuralist, Post-Structuralist, Semiotic, Deconstructive, Post-Colonial, Marxist, Feminist and Psychoanalytic theories (Allen, 2000). Intertextuality is roughly defined by Allen as "all that sets the text in a relationship, whether obvious or concealed, with other texts" (Allen, 2000, p. 101). Intertextuality for Genette is "a relationship of co-presence between two texts or among several texts" and as "the actual presence of one text within another" (Allen, 2000, p.101). The theory of intertextuality implies that "any one text is necessarily read in relationship to others" and readers draw upon a range of textual knowledge. These relationships are not in the form of specific allusions from one text to another and readers have no need to be familiar with specific or the same texts to get intertextuality (Friske, 1987, p. 108). As Montgomery (2007) states, the relationships between texts are vivid through interte xtuality, and indeed no text is unique.

Given the above mentioned definitions for intertextuality, there is an agreement about Last Orders' intertextuality among different critics. For example, Malcolm (2003) puts forward the idea that "Swift's scholarship has frequently shown that his novels constantly refer to the tradition of the canonical British nineteenth century novel. His novels, it is argued, echo and engage with those of Dickens, Throllope, George Eliot, and Hardy (p. 11). Malcolm also finds traces of Dickens and Hardy's fiction regarding the celebration of "working-class milieu." Furthermore, He finds "part of George Eliot's subject matter in Adam Bede [1859] and Mill on the Floss [1860]" since both Hardy and Eliot are "precursors of the detailed evocation of rural and small town settings" (p.12).

Cooper (2002) draws attention to the influence of Hardy on Swift in terms of "its combination of the specific and the universal as well as in many aspects of techniques" (P.14). She believes that "like Hardy's, Swift's fictions tend to be character-driven and philosophical, deeply concerned with both human psychology and the nature of our physical and spiritual lives" (p. 15).

Regarding the issue of intertextuality in Last Orders, Shaffer (2006) in Reading the Novel in English 1950-2006, states that "particularly strong echoes of two other modern novels resound in Last Orders: William Fau lkner's (1930) As I Lay Dying and Virgin ia Woolf’s (1925) Mrs. Dalloway" (p.199). He continues that,

as to the connection with Faulkner's novel, Swift himself attests to "a little homage at work": "I admire Faulkner very much, and there are obvious similarities" between the two novels. Yet while "I have my jar of ashes, Faulkner has his rotting corpse, and the setting is clearly very different." That said, for Swift the "funeral" emphas is, the story of "laying the dead to rest" and of "how the dead apply pressure on the living," is not so much a Faulknerian as a perennial, "primitive", "archetypal" concern. The fact that both novels feature a dead character whose remains are being transported and who narrates a small section of the text (Addie Bundren/Jack Dodds) has led one interviewer, John Frow, to accuse Swift of plag iarism (pp.199-200).

For Lea (2005) there is another source being drawn upon by Swift in Last Orders. He points to the climactic valediction on Margate Pier and draws attention to the following lines from T. S. Eliot's The Waste Land as being recalled by Last Orders: "on Margate Sands/ I can connect/ Nothing with nothing" and concludes that "the consonance between a poem and a novel that mourn the loss of western society's faith in the didactic institutionalization of belief is uncanny" (p.162).

According to what was mentioned earlier, especially significant is the effect of Faulkner's As I Lay Dying on Swift's Last Orders which is referred to by different critics. These similarities found between the two include going on a funeral journey, having multiple narrators whose names constitute the titles of chapters, having dead bodies to be transported according to their will, and having the dead to narrate a chapter of the novel. Still another conspicuous similarity between these two novels that implies the intertextuality is a very short chapter narrated by Vince and only two words "Old buggers" (LO 80). This is very similar to a chapter in As I Lay Dying in which the reader encounters a chapter of one sentence "my mother is a fish" (1930, p. 84). Still another short chapter in the novel is the one narrated by Lenny which is only a few sentences:

Canterbury Cathedral. I ask you. I should have kept my big trap shut.

Still, dose of holiness'll do us good, I suppose, the way things were going.

So glory be. Lift up your heats for Lenny (p. 127).

Tebbetts (2010) positively comments on the existing intertextuality between these two literary works. According to him "Swift chose to use As I Lay Dying as a model for the plot and narrative point of view of his 1996 novel Last Orders, he [Swift] suggested that in doing so he might have intended to engage the earlier novel in what Richard Gray has called the "open dialogue" among writers in the "vast sprawl" of the "literary tradition" (ix)" (p.1). He continues that in such an "open dialogue" Swift is in conversation with Faulkner and the aim is to grasp the other novel and then to respond to it (Tebbetts, 2010, p.1). Thus "looking past the imitations and toward the conversation lets the reader see just how fully Last Orders makes a productive response to As I Lay Dying” (Tebbetts, 2010, p.1).

It is also pointed out that "Swift's fascination with the family, and the disrupted family in particular, has its antecedents in Dicken's Bleak House and Eliot's The Mill on the Floss" (Malcolm, 2003, p.12). In terms of "the dark secrets hidden within these families (insanity, illeg itimacy, misplaced parents) [it] echo [es] Dickens and Wikie Collins" (Malcolm, 2003, p.12). David Malcolm positively concludes this intertextuality and presents that, "one can see Swift's novels are deeply and consistently intertextual, both on a local and a more general level....However, in overall terms, interte xtuality serves to universalize and to dignify particular characters and their fates" (Malcom, 2003). This is also in line with the advantage of intertextuality for Hatim and Mason (1990) as a "signifying system which operates by 
connotation" and broadens the domains of textual meaning. Thus intertextuality is not a foible but a forte for Last Orders adding to the already-existing layers of meaning.

\section{CHARACTER}

In Swift's Last Orders, there is a departure from conventional norms of character, dialogue, and narrative. In addition, the elements of pastiche, irony, parody, self-reflexivity, and absence of a frame of reference can be traced in his work. A postmodern atmosphere is enacted in Swift's Last Orders by these elements. As the novel unfolds, the situation of characters becomes more complex and ambiguous. This illustrates a degree of "semantic indeterminacy that is the frequent hallmark of postmodernist aesthetic production" (Murphy, 2003, p.187). The characters in the novel know the reason of their one-day journey for which they have come together, but they search for their past and explore their identities in a postmodern mood during the course of this "circadian" or "one-day novel" (Shaffer, 2006, p. 196). For characters in the novel, as Shaffer believes, "the limited present of the novel serves as an opportunity for character to recount and explore from their past lives. These memories and musings in turn illuminate and embellish the present of the narrative, which becomes considerably more resonant and complex in the process" (pp. 195-196). Shaffer also presumes that Swift draws upon "memory and the imag inative recreation of the past" in his novel to "reveal the extent to which national history and personal history are [...] knowable, ultimately and most fully, in subjective terms" (Shaffer, 2006, p. 197). Thus characters retell the past to make sense of their present situation. Hartung-Bruckner (2006) observes that, "the recurring concern with a reconstruction of family history highlights the longing for continuity and communication between the generations and sexes, both of which relationships are presented as contested, problematical, or even impossible" (p. 3).

Furthermore, the male characters in the novel ponder, philosophize, and agonize over grand issues such as the meaning of life as well as death which is dexterously represented through the characters' speeches or monologues; the male characters speculate on the time of their death and where and how they want to be buried which signals the moving impact of Jack's death and his ashes on characters and how they deeply delve into death. For example, Ray by telling that "the last of us to go" means to pass away like Jack Dodds; implies how deeply he is obsessed with death: "I'd [Ray] say Vic's looking the best of us all, by a long chalk. I'd say if you took Lenny, Vic and me, any one'd give Vic a five year advantage. It's a fair bet he'll be the last of us to go [my emphasis]. Excluding Vince, that is, and he aint no spring chicken" (LO, p. 51).

The novel is made pluralistic through complexity, undecidability, and openness of the text in exploring new traces of ideas which result in representing its postmodernity and liberating it from dominant logocentric thought. The demonstration of the postmodern condition of characters is further hinted by unstability of the main characters' identity as well as the novel's language.

\section{RESI STING INTERPRETATION: AMBIGUITY, COMPLEXITY, DIFFERANCE}

Under the guise of what follows as Ambiguity, Complexity, and Differance, resistance in the novel is not only possible but also actualized.

\section{A. Ambiguity}

Lyotard (1984) has asserted that:

The postmodern artist or writer is in the position of a philosopher, the text he writes, the work he produces are not in principle governed by pre-established rules and cannot be judged according to a determining judgment, by applying familiar categories to the text or to the work. Those rules and categories are what the work of art is looking for. The artist and the writer, then, are working without rules in order to formulate the rules of what will have been done (p. 81).

The verbalized chaotic nature of modern life in texts written by a postmodern writer or works produced by a postmodern artist "is not governed by pre-established rules" (Lyotard, 1984, p. 81). In Last Orders, attention is drawn toward the ambiguity of the ambiguous and ill-defined physical world which is inhabited by characters from the very beginning: "it aint like your regular sort of day" ( $L O 2$ ). Ray, the title character, begins the novel with the simple activity of ordering Bernnie "to pull" him "a pint and puts it in" ( $L O 2$ 2) and after four pages of ambiguous dialogues and keeping the reader in the a mbiguous world created by them, the reader gets to grasp the information about their purpose of gathering in the pub. Consider the following dramatic monologue:

$\mathrm{He}$ [Vic] twists the box round so we [Ray and Lenny] can see there's a white card sellotaped to one side. There's a date and number and a name: JACK ARTHUR DODDS. ( $L O$ 4)

Here the purpose of their gathering is somehow revealed and it is to scatter Jack Dodds' ashes according to his wish before his death. Cooper (2002) states, "in Swift's novels, a simple plot usually provides the opportunity for a profound study of character, and a complex journey into the human psyche. As a writer deeply interested in the mind and its relationship to the heart, Swift uses plot as a point of departure for exploring the personalities and relationship s of his vivid individuals" (p. 22). Ontological explorations are possible in an ambiguous world where boundaries are removed. This makes the imagination flowing and at work for making meaning.

\section{B. Complexity}


Multiple meanings could be extracted from every sentence of the novel and its title which makes sense depending on the angle from which the case is considered. According to the above-mentioned idea, the title of the work refers to various meanings. Malcolm (2003) nicely comments on the possible meanings of the title, Last Orders:

Graham Swift's sixth novel is prefaced by two epigraphs that neatly sum up the concerns, the milieu, and the powerful paradoxes of the text. The first comes from Sir Thomas Browne's grandiloquent meditation on funerals, Urn Burial (1658). The quotation reads: "But man is a Noble Animal, splendid in ashes and pompous in the grave." The second epigraph quotes the author (John A. Glover-Kind) of a popular music hall song first published in 1907: "I do like to be beside the seaside." Browne's sentence is impressive, archaic, and sonorous, touching on last things; GloverKind's song captures a fun-seeking, saucy, seedy, lower-class world of Edwardian and 1930s seaside resorts. Last Orders embraces both intellectual and social worlds. It is a complex meditation on grand, universal matters; it is set in a lower class world of nonstandard dialect, mundane work in shops and offices, and trips to the seaside. The title of the novel itself embodies this paradox. "Last orders" are the final drinks one can obtain in a British pub before it closes. "Last orders" also suggest last things, death, morta lity, and the inevitable passage of time (p. 158).

According to Parker (2003), Last Orders refers to "male order and the end of masculinity" and,

situates Swift's character within a patriarchal social order. On the most immediate level, it refers to the last orders of Jack Dodds [...] but it simultaneously introduces the theme of male authority and evokes a number of male-dominated institutions that signal Swift's interest in masculinity: the pub, the church, and the armed forces. The masculine names of the pubs where the men drink denote that they are predominately male spaces: the Green Man, Thomas a Becket, lord Nels on (Swift, 1996: 17), the Prince of Windsor (p 18), and the Bull. (p. 90).

It is also said that, "the title relates to the men's service in the armed forces, a traditionally all-male and still maledominated organization based on orders. All of the central protagonists have served in the armed forces, and Lenny's comment indicates the degree to which they are shaped by their military experience that puts a finish on man. This complexity is further strengthened through the use of narrational techniques and multiple tellers as Malcom (2003) puts it: "the novel's narrational technique and narrative organization contribute toward the reader's sense of character complexity" (pp. 170-171). Furthermore, the title is also part of a sentence in which Ray and Jack are talking about Coach and Horses and Ray says, "it was coming up to last orders" $(L O$ 6) hence a part of the sentence becomes the title and adds to the complexity.

Wheeler (1999) argues that "Swift's fiction explores the loss of traditional forms of knowledge in a secular postmodern world and is concerned with new ways of being in the face of uncertainty" (pp. 64-65). In contrast to Wheeler who argues that the novel's obsession is the invocation of order, Parker (2003) refers to the limits of masculinity and represents patriarchy as a lost order. Regard ing the same idea, Shaffer (2006) calls attention to the point that "both Swift's title and the location of the final scene subtly evoke T.S. Eliot's The Waste Land, which mourns what is portrayed as last orders for European civilization [...] and expresses profound anxiety about the disruption of traditional class and gender boundaries" (p.199).

\section{Differance}

Around 1967 in Paris, a novel intellectual movement took the place of Structuralism which emerged in the work of some French thinkers like Jacques Derrida, Ju lia Kristeva, Gilles Deleuze, Luce Irigaray, Helen Cixous, Jean-Francois Lyotard, and Jean Baudrillard. This new movement was usually referred to as Post-structuralis mand the reason lying at the heart of this title was the radical departure of the basic assumptions of Structuralism. Deconstruction is the name of a method of critique that was developed by Jacques Derrida, "whose writing is central to the emergence of Poststructuralis m" (Rivkin \& Ryan, 2004, p. 257). Thus "deconstruction" is another term that widely is associated with Post-structuralism. In addition, it also takes into account the idea of defining Derrida's work by the word "deconstruction." Martin McQuillan (as cited in in Rivkin \& Ryan, 2004, 24) observes that "deconstruction is not a school or an "is m." There is no such thing as "deconstructionism;" this is a word used by idiots."

As Derrida has remarked there is no "univocal definition" or "adequate description" for this eccentric phenomena called "deconstruction," and the reason for "this absence of univocal definition is not 'obscurantist" " but rather it is related to a new en lightenment (Rivkin \& Ryan, 2004, p. 24). According to what Royle (2003) states, Derrida's texts have been more effective than other contemporary writers, and they "describe and transform the ways in which we think about the world, about life, death, culture, philosophy, literature, politics, and so on" (p. 21). He presumes that Derrida has written again and again and always differently to produce "a force of dislocation that spreads itself throughout the entire system" and about deconstruction as "de-sedimentation," about "a force of irruption that "[disorganizes] the entire inherited order" (p. 25). He dubs deconstruction as an earthquake. Royle (2003) also believes that deconstruction is about "shaking up, dislocating and transforming the verbal, conceptual, psychological, textual, a esthetic, historical, ethical, social, political and religious landscape. Its concern is to disturb, to de-sediment, to deconstruct" (p. 25). Stocker (2006) says in the account of deconstruction by Derrida that "the ideas of duality and equivocation are constant" (p.168). Royle also goes further by drawing on the idea that deconstruction is a "strange strategy without finality" which "encourages a critical questioning of any and all kinds of religious or political discourse that make dogmatic assumptions about the nature of presence and what might be meant by 'the end" "(p. 35).

The concept of "Differance" introduced by Derrida lies at the heart of deconstruction - he also introduces the ideas of multiplicity, heterogeneity, and plurality of meaning. Derrida declares in the 1968 essay that differance is "neither a 
word nor a concept." He continues that difference "is not a name;" [...] "is" what makes presence possible while at the same time making it differ from itself" (Royle, 2003, p.71). Saussure's concept of the diacritical nature of the linguistic signs was the focus of Derrida. According to this concept the differences of a sign from others constitute its identity. Therefore, Derrida concluded that "there had to be a more primordial process of differentiation at work that affected everything having to do with language, thought, and reality" (Rivkin \& Ryan, 2004, p. 258). He called this primordial process "differance" which means "a simultaneous process of deferment in time and difference in space" (Rivkin \& Ryan, 2004, p. 258). He continues that "one present moment assumes past present moments as well as future present moments; to be "present," a present mo ment presupposes its difference from other presents." Similarly, "the presence of an object of conscious perception or of a thought in the mind is shaped by its difference from other objects or thoughts." Thus Derrida by "differance" means "simultaneous movement of temporal deferment and spatial difference both ongoing processes that constitute being" (Rivkin \& Ryan, 2004, p. 258). The denotation of the verb "to differ" [differer] seems to differ from itself. It indicates, on the one hand, difference "as distinction, inequality, or discernability;" on the other hand, it "expresses the interposition of delay, the interval of a spacing and temporalizing that puts off until "later" what is presently denied, the possible that is presently impossible" (p. 279).

According to McHale (1987), "the dominant mode of modernist fiction is epistemological" (p. 9) and therefore, the modernist fiction concentrates on repetition and uniformity and "rewards interpretation" which is in sharp contrast to differance; differance is in agreement with ontological poetics of postmodernism that "frustrates interpretation" (Nicol, 2009, p. 60). In other words, "in postmodernist texts [...] epistemology is backgrounded, at the price of foregrounding ontology" (McHale, 1987, p. 11). Graham Swift does not provide the reader with a definite, logocentric text thus it does not lead to a decidable meaning. The reader is actively involved in the text since differance is applied in the novel by Swift that aims at challenging the reader's perception and understanding of the novel. In supporting the same idea, when Swift is interrogated the question, "what does water mean to you?" by Lewis Burke for the Journal Winter, his reply is evocative: "I have kind of resisted the connection" which is in line with the idea of frustrating interpretation. Therefore, by drawing on the previous discussion on the possible meanings that can be implied by the title, it could be concluded that there is a lack of determinate meaning that is in agreement with post-structuralism deconstruction and creates ontological instability, a dominant feature found in postmodern ist texts.

\section{TOWARD DELOGOCENTRISM}

Derrida did research on the relationship between language and reality in his texts, Writing and Differance and Of Gramatology. As it can be understood from his texts, he denies the stability of signification s ystem and the presupposed stability between them and questions the validity of "Logocentrism." According to him (1978), for finding meaning, there is no pre-existent truth, "transcendental signifier" or "logos" to appeal to. As Ulmann (1999) puts it, his "deconstruction affirms the importance of a mbivalence, of the relation between terms rather than the choice of o ne term over another" (p. 23).

The proposed delogocentrism by Derrida rejects the feasibility of discerning transparency in language and proves that "the central signified, the originality, or transcendental signified is revealed to be never absolutely present outside a system of differences, and this absence of an ultimate signified extends the domain and play of signification to in fin ity" (as cited in Lodge \& Wood, 2000, p. 246). Swift, in order to free himself from the boundaries of language and text, draws on this potentiality. He is like most postmodern writers and unlike metaphysical thinkers and philosophers who try not to encounter multip lic ity of meaning or ambiguity of a written text. In Last Orders, as the title speaks for itself, the credibility of "the metaphysics of presence" is lost, since from the onset talking of last things is mentioned. Last Orders refers to the last will of the deceased Jack Dodds who is to be absent during the course of the novel, but he is present which simu ltaneously aims at prompting his friends and readers to reconsider their lives. Thus the reader should understand this absence and presence; the ambivalence of presence/absence contributes to Derridean idea remarking that in postmodern thought and literature there could not exist sacred-text and author-God. Thus the access to the signified is made infeasible and the truth remains far-fetched.

It can be inferred that through the application of above mentioned techniques Graham Swift succeeded in demonstrating the "inadequacy of meaningful narrative" which is the product of "deligitimation" according to Lyotard (1984): it is the process in which grand narratives lose their power to legitimize discourses.

\section{MINIMALISM}

The origin of minimalism, as a peculiar movement in arts, lies in the early $20^{\text {th }}$ century modernist experiments with form. Since contemporary writers use such strategies in the late-modern ist form, it can be regarded as both a bridge and continuation of these strategies to postmodern art assiduities. Mason (2007) presumes that

minimalist texts are often constituted by fragments that have little narrative continuity even if they develo $\mathrm{p}$ a consistency of thematic tropes... The exhaustion of language and narrative is often an important feature of minimalis $\mathrm{m}$... where enervation, repetition, and disconnection (textual, cultural, and cognitive) are significant tropes. Minimalis $m$ is particularly concerned with the reduction of the self and consciousness... in this case the production of a 
text is an attempt that fails because of the necessity of using language which is the case of frag mentation in the first place (p. 210).

Although Swift may not be regarded as a genuine devoted minimalist such as Samuel Beckett, the footprints of providence with words and an epitomizing on surface description can be pinpointed in his text. Like most minimalist writers, he allows context to dictate meaning. This technique results in keeping the reader on his toes to create the novel's story based on oblique hints and clues rather than reacting to directions from the author. Thus the readers are expected to take an active role in making sense of the text as Malcolm (2003) states that "the Swiftian narrators' speech is distinguished by incomplete utterances (frequently as aposiopesis - the intentional failure to complete a sentence). Many narrators allow their utterances trail off into dashes and ellipsis points" (p. 15). Their utterances end either in incomp lete sentences or starts with ellipsis in which using of dots [...] is outstanding. For example, in a chapter told by Ray there is an incomplete sentence as follows: "it's just the gypsy in my..." (LO 112); or in another chapter narrated by Vic the sentence starts by some dots: “... we therefore commit their bodies to the deep" ( $L O$ 84). This feature hints the idea that there are some realms that the narrator does not want to share with the reader or s/he is unable to convey it to the interlocutor. In addition, there are sometimes pages where characters swap phrases that are just a few words long:

Jack says, "You've only got an hour of it left."

Mandy says, "Better make the most of it."

Lenny says, "Promises."

Vince says, "Never know your luck" ( $L O 7$ ).

Silence is another significant feature of minimalis $\mathrm{m}$ as well as postmodernism. Mason states that silence is the only response being drawn upon when there is an inability in expressing the self or reality as meaningful entities. Thus the preoccupations of minimalism are negativity, absences, and the unspoken, which result in creating a significant generative principle in text, particularly in a sort of paradox that minimalism both carves for and is afraid of which is silence (Mason, 2007, pp. 210-211). According to Malcolm (2003):

the Swiftian's narrators' speech is distinguished by incomplete utterances [...] [and the reader gets] a strong sense that some characters are unwilling to say certain words, or to look at certain issues directly. This is coupled with one's sense that there are deep silences in some narrators' lives, areas of their experience that will avoid at all costs (p. 15).

These silences support the fact that the characters lack the ability to express the reality in their minds or their identities.

\section{CONCLUSION}

Last Orders enjoys some superficial similarities in plot to William Faulkner's As I Lay Dying (1930). It endorses both modernist and postmodernist features but the postmodernist features are more significant and apparent. After applying Jean Francois Lyotard's theory of the end of grand narratives and Jacques Derrida's deconstruction, it is fa ir to dub Last Orders a postmodern work.

A real portrait of postmodern condition is depicted by Graham Swift in Last orders. The novel is a complex one and enjoys semantic indeterminacy which according to Murphy (1992) is "the frequent hallmark of postmodernist aesthetic production" (p. 187). The dominance of ontological poetics is conspicuous in the novel and according to McHale this is in sharp contrast to modernism in which epistemology is more apparent. The characters search their identities and recreate and retell the past to make sense of their present situation. The ambiguity is presented from the out set and thus it gives a postmodern atmosphere to the setting of the novel and situation of characters. Therefore, Last Orders frustrates any specific interpretations due to the novel's resistance against being interpreted.

Another obsession of Swift's novel is Lyotard's idea regarding the end of grand narratives. Complexity, a mbiguity, and differance demonstrate the "inadequacy of meaningful narrative" which is the product of "deligitimation;" according to Lyotard "deligitimation" is the process in which grand narratives lose their power to legitimize discourse (Lyotard, 1984).

The novel does not provide a definite meaning which results in ambiguity and hence lack of closure. Therefore, the reader has to make sense and take on the responsibility of getting meaning according to the viewpoint s/he considers the text.

The last but not the least, minimalis $\mathrm{m}$ is a recurrent postmodern feature apparent in the works of this era. Short sentences and unspoken realities are the outcome of minimalism in this novel. Silence is another feature related to minimalis $\mathrm{m}$ in which characters remain silent or their speeches end in dashes or dots resulting in the perception of the point that some private domains of characters are not allowed to be trodden by the interlocutor.

\section{REFERENCES}

[1] Allen, G. (2000). Intertextuality. London: Routledge.

[2] Bauman, R. (2004). A World of Other's Words: Cross-Cultural Perspectives On Intertextuality. USA: Blackwell.

[3] Cooper, P. (2002). Graham Swift's Last Orders: A Reader's Guide. New York: Continuum.

[4] Derrida, J. (1978). Writing and Difference (A. Bass, Trans.). Chicago: The University Of Chicago Press.

[5] Friske, J. (1978). Television Culture: Popular Pleasures and Politics. London: Routledge.

[6] Faulkner, W. (1990). As I Lay Dying. New York: Vintage International. 
[7] Gale, M. R. (2000). Virgil on the Nature of Things: The Georgics, Lucretius and the Didactic Tradition. Cambridge: Cambridge University Press.

[8] Hartung-Bruckner, H. (2006). (Re) constructions of History and Deconstructions of "Englishness". "History and "Englishness" in Graham Swift's Last Orders. Institute fur Englische Philologie, Freie Universitat Berlin. Retrieved from http://www.postcolonialweb.org/uk/gswift/lastorders/hhb3.html (accessed 28/03/2012).

[9] Hatim, B., \& Mason, I. (1990). Discourse and the Translator. London: Longman.

[10] Lea, D. (2005). Graham Swift. Manchester, England: Manchester University Press.

[11] Lodge, D., \& Wood, N. (2000). Modern Criticism and Theory: A Reader. London: Longman.

[12] Lyotard, J. (1984). The Postmodern Condition: A Report on Knowledge (G. Bennington \& B. Massumi, Trans.). Manchester: Manchester University Press.

[13] Malcolm, D. (2003). Understanding Graham Swift. Columbia: University of South Carolina Press.

[14] Mason, F. (2007). Historical Dictionary of Postmodernist Literature and Theatre. Lanham: Scarecrew Press.

[15] McHale, B. (1987). Postmodernist Fiction. Methuen.

[16] Montgomery, L. M. (2007). Ways of Reading: Advanced Reading Skills for Students of English Literarture. London: Routledge.

[17] Murphy, P. D. (1992). Staging the Impossible: The Fantastic Mode in Modern Drama. Westport: Greenwood Press.

[18] Nicol, B. (2009). The Cambrid ge Introduction to Postmodern Fiction. Cambridge: Cambrid ge University Press.

[19] Parker, E. (2003). No Man's Land: Masculinity and Englishness in Graham Swift's Last Orders. Posting the Male: Masculinities. In D. Lea, \& B. Schoene-Harwood (eds). Post-War and Contemporary British Literature (pp. 89-104). Amesterdam:Rodopi.

[20] Rivkin, J., \& Ryan, M. (eds). (2004). Literary Theory: An Anthology (2nd Ed). UK: Blackwell Publishing.

[21] Royle, N. (2003). Jacques Derrida. London: Routled ge.

[22] Shaffer, B. W. (2006). Reading the Novel in English 1950-2000. Blackwell Publishing.

[23] Stocker, B. (2006). Routled ge Philosophy Guidebook to Derrida on Deconstruction. London: Routledge.

[24] Swift, G. (1996). Last Orders. http://www.library.nu/ebooksclub_last orders (accessed 17/10/2011).

[25] Tebbetts, T. L. (2010). Discourse and Identity in Faulkner's as I Lay Dying and Swift's Last Orders. The Faulkner Journal, Mar. 22, 2010. Retrieved from http://www.thefreelibrary.com (accessed 28/03/2012).

[26] Ulmann, A. (1999). Beckett and Poststructuralism. Cambrid ge: Cambridge University Press.

[27] Wheeler, W. (1999). Melancholic Modernity and Contemporary Grief: The Novels of Graham Swift. In R. Luckhurst \& P. Marks (Eds). Literature and the Contemporary: Fictions and Theories of Present (pp. 63-79). Harlow: Pearson Longman.

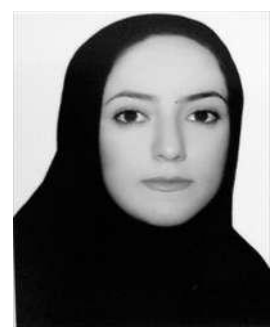

Razieh Abdi was born in Ilam, Iran in 1983. She received her B.A. degree in English Lan guage and Literature from Ilam University, Ilam, Iran in 2010 (as the top student); she also got her M.A. in English Language and Literature from the University of Isfahan, Isfahan, Iran in 2012.

She has been teaching English as a foreign language in Ilam since 2007. She also presented a co-authored paper on WTC (Willingness To Communicate) which was published in International Education Studies in November $1^{\text {st }}, 2011$

Ms. Abdi is now teaching as an English teacher at the three branches of Alpha Institute, the biggest Lan guage Institute in Ilam, Iran.

Pyeaam Abbasi was born in London, England in 1977. He got his Ph. D. in 2011 from Shiraz University and is assistant professor of English Literature at the University of Isfahan. He is currently assistant to the head of the English department at the University of Isfahan. 